\title{
Women's Agency in Peacebuilding in Polarized Post-Conflict Communities in Plateau State, Nigeria
}

\author{
Kwopnan Ibrahim Bulus ${ }^{1}$, Feyza Bhatti ${ }^{2} \&$ Cemaliye Beysoylu ${ }^{1}$ \\ ${ }^{1}$ Department of Politics and International Studies, Faculty of Business \& Economics, Girne American University, \\ Turkey \\ ${ }^{2}$ Department of Economics, Faculty of Business \& Economics. Girne American University, Turkey \\ Correspondence: Kwopnan Ibrahim Bulus, Department of Politics and International Studies, Faculty of Business \\ \& Economics, Girne American University, University Drive, Girne - North Cyprus via Mersin 10 - Turkey. \\ E-mail:kapal4uall@gmail.com
}

Received: March 19, 2020

Accepted: April 16, $2020 \quad$ Online Published: May 25, 2020

doi:10.5539/jpl.v13n2p189

URL: https://doi.org/10.5539/jpl.v13n2p189

\begin{abstract}
Over the last two decades, while significant consideration is given to women's participation and representation in formal peacebuilding processes, there is the dearth of research on the grassroots level involvement and contributions of women to peacebuilding processes in post-conflict communities. Utilizing 28 semi-structured interviews and two focus group discussions with women in Bukuru and Gyel communities, this article aims at improving the understandings on the agency of women in building and sustaining peace in polarized post-conflict communities in Plateau State, Nigeria. The article argues that in spite of the global marginalisation of women in formal peace processes, women are actively involved in peacebuilding and use various forms of individual and collective agency to restore harmonious relations, build peace and foster social cohesion in polarized post-conflict communities.
\end{abstract}

Keywords: peacebuilding, women's agency, bottom-up peacebuilding, social cohesion

\section{Introduction}

Prior to the September 2001 conflict, Plateau State ${ }^{1}$ has always been considered as one of the most peaceful states in Nigeria where inter-ethnic and inter-religious relations were harmonious. ${ }^{2}$ However, things changed when series of violent ethno-religious conflicts disrupted the peace in the state between the periods of 2001 and 2011, leading to the death of as many as 7000 people; the wanton destruction of properties; the loss of means of livelihood; the loss of access to essential services and the displacement of people within Jos and other parts of the State (Krause, 2018). There have been divergent views on the causes of conflict in the State. While some scholars assert that the issues that led to the conflicts bother on local elite competition and indigeneity (Danfulani \& Fwatshak, 2002; Best 2007; Madueke, 2018; Krause, 2019), some others relate it to religious factors (Harnischfeger, 2004; Sodiq, 2009), competition over the ownership or allocation of resources (Ostien, 2009; Ambe-Uva, 2010) and the politics of identity or rather ethnicity (Egwu, 2004; Adetula, 2005; Ostien, 2009; Ambe-Uva, 2010). Although the conflicts in the State are linked to these issues, violence has always assumed a religious dimension (Best, 2007; Ostien, 2009; Milligan, 2013; Madueke, 2018).

The protracted conflict in Plateau State has no doubt left an indelible mark in the state which is evident in the religiously polarized settlement pattern (Aliyu, Abdullahi, Rozilah, Kasim \& David, 2015) in some post-conflict communities in Jos North and Jos South Local Government Areas. In such communities, the settlement pattern depicts Christians on one side of the divide and Muslims on the other with an invisible border ${ }^{3}$ which is respected by both sides of the divide. This, however, has given room for a high level of mistrust, mutual suspicion and severed relations between the inhabitants of the settlements (Mustapha, Higazi, Lar \& Chromy,

\footnotetext{
${ }^{1}$ Plateau State is one of the 36 State in Nigeria. It is located in North-Central geo-political region of Nigeria.

${ }^{2}$ The peaceful and harmonious relations among the over 50 diverse ethnic groups in the state graced it with the slogan 'Home of Peace and Tourism'.

${ }^{3}$ The term in this article refers to non-physical borders between communities; or rather an imagined borders based on the religious groupings occasioned by the conflicts and violence.
} 
2018).

Over the years, the major efforts put in place by the State government for conflict management, resolution and peacebuilding have been following a top-down approach ranging from the establishment of a peacekeeping Special Task Force (STF), ${ }^{4}$ Operation Rainbow, ${ }^{5}$ as well as the establishment of the Plateau State Peacebuilding Agency (Krause, 2019). These efforts and initiatives have immensely contributed to the cessation of violence, but they have not been able to expunge the mutual suspicions, enmity and build social cohesion in the polarized post-conflict communities (Mustapha et al., 2018). Although previous studies on conflict and peacebuilding in Plateau State such as Danfulani and Fwatshak (2002); Adetula (2005); Best (2007); Gwamna (2010); and Bonkat $(2014 ; 2015)$ have provided insights on the historical perspectives of the conflict, causes of the conflict, the various conflict resolution initiatives by the government and women as survivors of conflict, women's agency in peacebuilding at the community level is yet to be explored.

Feminist scholars argue that conflict is gendered (Alison, 2009; Moser \& Clark, 2001). As such, the experiences and activities of women during conflict and post-conflict often differs from that of men (Alison, 2009; Marchbank, 2000; Mbabazi, Naiga, \& Helen, 2020). While limited participation of women in formal peace processes remains as a concern at the global level, their contributions to peacebuilding at the grassroots level are far from being recognised. Some scholars argued that there is a higher possibility for attaining the cessation of violence and stability when there is equal participation of women and men in peace processes at all levels (Krause, 2019; Mbabazi, Naiga, \& Helen, 2020; Noma et al., 2012; Olsson \& Gizelis, 2014). However, there is still a gap in the understandings of the pathways through which women facilitate reconciliation, friendliness, and harmonious relationships in religiously polarized post-conflict communities. Are women able to transform broken relationships between polarized post-conflict communities? If so, through what ways? This article aims to explore women's contribution to peacebuilding by focusing on how women are transforming broken relationships and building social cohesion in the polarized post-conflict communities through their agency. In a broader sense, the paper also contributes to the existing literature on peacebuilding and gender studies by bringing an interdisciplinary lens to understand women's contribution to peacebuilding at the grassroots level.

The article is structured and organized in the following subsections: While the first section focuses on the conceptual clarification of peacebuilding and linking women's agency as a bottom-up approach to peacebuilding, the second section discussed the methodological approach and the empirical data. The third section explores women's agency in peacebuilding in the polarized communities.

\section{Peacebuilding and Women's Agency: A Bottom-up Approach}

The term peacebuilding was present in scholarly debates in the 1970s, although it only became very popular after it was used in 1992 by the then UN Secretary-General Boutros Boutros-Ghali in his 'Agenda for Peace'. The coining of the term is traced to the work of Johan Galtung (1976) who distinguished peacebuilding from peacekeeping and peacemaking, and argued that peacebuilding should be seen in relation to the structure of peace. Peacebuilding structures should go in tandem with peacekeeping and peacemaking to remove the causes of wars and create viable options to war in situations where there is a likelihood of the occurrence of war (Oda, 2007; Ramsbotham et al., 2005). These options, according to Boutros-Ghali should include a wide range of activities that are needed to "identify and support structures" that have the capacity to "strengthen and solidify peace" so as to prevent the relapse to violent conflict in societies (Boutros-Ghali, 1992, p. 11).

Since Boutros-Ghali's speech, the concept of peacebuilding has been constantly expanding to incorporate more activities and actors for achieving sustainable peace. A very important expansion of the conceptualisation of peacebuilding relevant to this study is that of Lederach (1997), who defines peacebuilding as:

A comprehensive concept that encompasses, generates, and sustains the full array of processes, approaches, and stages needed to transform conflict toward more sustainable, peaceful relationships. The term thus involves a wide range of activities that both precede and follow formal peace accords. Metaphorically, peace is seen not merely as a stage in time or a condition. It is a dynamic social construct. (Lederach, 1997, p. 20)

Lederach's peacebuilding differs from that of Galtung whose idea precedes the ambiguity of the concept that emerged after the Cold War. As stated earlier, Galtung's peacebuilding focused on the structures that are put in place to remove the causes of war as well as proffer alternatives to war. Central to Lederach's definition is his argument that the goal of peacebuilding should be the transformation of conflict rather than placing emphasis on

\footnotetext{
${ }^{4}$ The STF is composed of personnel of the Nigerian Armed Forces and Mobile police brigades

${ }^{5}$ This is a state security outfit set up by Plateau State government composed of policemen and vigilante groups for early warning.
} 
the structural components of peacebuilding (Lederach, 1997). Thus, by transformation, emphasis is placed on the process of redefining and establishing of new patterns of relationships for conflicting parties which encompasses different elements that are necessary to build peace in a society (Lederach, 1997). Peacebuilding is not a one-time off activity, but rather, it is a long-term process that requires continuous engagement and covers all efforts that are aimed at pulling down all structures of violence and building structures of peace. The durable social change (i.e. peace) necessitates the participation of different actors who act simultaneously in order to achieve sustainable peace (Lederach, 1997; Mac Ginty, 2014). Lederach (2012) identifies three levels of actors in peacebuilding i.e. the top level which is the first consist of policymakers; the second level is the mid-level which consist of opinion leaders, key influential sectors of the society; and the third is the grassroots level constituted by local leaders, group and individuals (Lederach, 1997). In addition, conflict transformation recognizes that peace agreements are capable of putting an end to the violence in a society but it lacks the capacity to address the animosity that exists between conflicting parties which requires a more engaged process to be addressed. For such an engagement, greater involvement of the grassroots or local ownership of the peacebuilding process i.e. a bottom-up approach led by local non-state actors is also necessary.

However, a majority of the literature on peacebuilding appears to place more emphasis on the top-down approach. ${ }^{6}$ This perhaps could be due to the fact that peacebuilding in conflict situations at inception began as an external effort which included the use of international intervention forces (Keating \& Knight, 2004; Paris, 2004). Then, peacebuilding efforts was a top-down effort through international agencies aimed at transforming war-torn states in accordance with the tenets of liberal internationalism - liberal democracy and market economy (Paris, 2004). The process had to do with the assumption that with the establishment of democratic and economic liberalism, war-torn states would be peaceful like the Western liberal market democracies (Jeong, 2002). The top-down approach did not pay much attention to the actions of the local actors but rather considered the local actors as implementing partners (Jeong, 2002).

The importance of the local ownership of the peacebuilding process became more evident in the post-Cold War era when we witnessed a change in the nature of conflicts from interstate to intrastate. As such, it became imperative that the strategies to address the conflicts are also revisited and changed. Thus, scholars such as Lederach (1997); Galama and Tongeren (2002); Tongeren et al. (2005); Paffenholz and Spurk (2006); and Gawerc (2006) all hold that there is a need for an alternative approach to top-down peacebuilding i.e. bottom-top approach which will entail peacebuilding initiatives from the grassroots in which local actors can develop and adopt practical solutions to conflicts that can lead to sustainable peace. Peacebuilding from the local level which is a 'microcosm' of the conflict's dynamics can bring about social transformation (Bar Tal, 2013) and play a major role in the transformation of conflict as all aspects of the conflict to be addressed (Paffenholz, 2014). Social transformations at the local level in line with Lederach's view involves all groups including women.

Despite the role of women during conflicts - whether as combatants, victims or advocates of peace, women have been marginalised during formal post-conflict peacebuilding processes. Even after the adoption of the UN Security Council Resolution 1325, which encourages all member states to increase the participation of women in all peacebuilding processes at international, regional or national levels, women's formal involvement in peace processes remained minuscule. From 1992 to 2018, women were only 3\% of mediators, 4\% of signatories and 13\% of negotiators (Council on Foreign Relations (CFR), 2019). Evidence, however, has shown that when there is the involvement of women in peace agreements, the agreements are $64 \%$ less likely to fail and $35 \%$ more likely to last at least for 15 years (CFR, 2019). Also, other previous research suggest that women's contribution is not only limited to formal processes. At the grassroots level, they have a rather subtle but substantial role in peacebuilding through their informal activities. For instance, Women in Black in Israel had silent vigils to protest conflict in public places (Kaufman \& Williams, 2013), in South Africa, the Harambe Women's Forum was formed by local women to rebuild their devastated communities for durable peace (Noma, Aker and Freeman, 2012), also women in Liberia had 'Liberia Mass Action for Peace' campaign to ensure a ceasefire and end the second Liberian civil war in 2003 through their mass actions such as sex strike and nonviolent protests (Alaga, 2010). Similarly, women also act as intermediaries to avert the relapse to violence as it was in post-genocide Rwanda, where women acted as intermediaries and facilitated dialogue and reconciliation between their relatives and the government troops (Adeogun \& Muthuki, 2018). These examples from different parts of the world show that peacebuilding processes can be strengthened by various localized activities carried out through women's agency.

Women can exercise their agency individually or collectively (Gardner, 1995; Kabeer, 1999). It could be

${ }^{6}$ This was mostly carried out by external actors like the International Institutions and State governments. 
considered as a form of the bottom-up approach to peacebuilding which allows women to participate in the process of social transformations. The concept of agency as defined by Rodríguez, Pillai, and Ferreira (2016, p. 25) signifies "a process of change where people start becoming aware of their power, possibilities, and influences in different groups and environments". This suggests that it has to do with the ability of both individuals and groups to effectively make choices that has the capacity to influence changes to prevailing values and norms into their desired outcomes. Women's agency basically focuses on the ways in which women are able to progress towards the desired outcomes by challenging the status quo by thinking outside the system (Kabeer, 2001). Mishra and Tripathi (2011, p. 59) emphasize that it can be "operative when it results in a fundamental shift in perceptions, or "inner transformation" so that women are able to define self-interest and choice, and consider themselves as not only able but entitled to make choices". Agency is a relative concept, as such, women's agency is expressed in numerous ways such as participation in politics, the ability to acquire education, rights as well as autonomy.

In this article, we consider women's agency in peacebuilding to mean women's individual and collective efforts to transform hostility and initiate social changes that can prevent the relapse to violence, build peace and social cohesion in their communities. Through bringing the concepts from political science and gender studies, we argue that the daily agency of women in peacebuilding has the potential to change perceptions, build trust, mutual cooperation and build peace in polarized post-conflict communities where relations have been severed. In the subsequent sections, we will elaborate on this to show how women are able to act individually and collectively irrespective of their religious differences to change perceptions, sustain themselves and build peace.

\section{Methodology}

A qualitative phenomenological approach was adopted to capture and understand the women's lived experiences during and after conflict, and their involvement in peacebuilding activities individually or collectively within their local communities. Qualitative approach, which is also feminist sensitive, can enable the exploration and understanding of the different meanings women ascribe to social problems such as conflict and how they dealt with these problems (Creswell, 2009). It also creates an avenue where the voices of women can be heard and give room for the realization of their emancipatory goals (Bryman, 2008). Interview and Focus Group Discussions (FGDs) were used as the methods for data collection which allowed the women in their own voices to articulate their experiences, efforts and the key factors that encouraged their agency in peacebuilding.

\subsection{Research Setting}

This article is based on field research in Bukuru and Gyel neighbouring communities in Jos South Local Government Areas (LGA) in Plateau State between May and October 2019. Prior to the 2001 conflict in Plateau State, Bukuru and Gyel were ethnically and religiously mixed communities where Christian and Muslims coexisted peacefully (Krause, 2018; Madueke, 2018). Consequently, the protracted ethno-religious conflict in the state (between 2001 and 2011) created a new settlement pattern along religious lines (Aliyu et al., 2015; Madueke, 2018). While presently Bukuru is categorized as a predominantly Muslim community, Gyel is inhabited by predominantly Christians.

\subsection{Sampling Strategy and Recruitment of Participants}

A purposive sampling strategy was used to recruit the participants. The sampling strategy for recruitment of participants for the interviews and FGDs were purposive to maximize the inclusion of informants/participants who were the residents of these communities since after the 2001 conflict and thus have experienced the conflict and the peacebuilding efforts of the communities afterwards. The women leader in Gyel community who was first interviewed by the first author served as a gatekeeper for both communities and assisted in gaining rapport with the participants. The participants were mainly accessed through snowballing techniques. In order to minimize the possibility of remaining in a small group of participants, we gave importance to have multiple initial contacts.

The ethical approval for the research was obtained from the university, where the authors are affiliated with. Further verbal permissions were also taken at the community level from the gatekeepers before approaching the participants. The participants were not given any consent forms to sign as signing any document would create concerns about the anonymity of the research and the intentions of the researchers. Participants, however, were duly informed by the first author on the purpose of the research, voluntary nature of the study, their right to withdraw, management of data, anonymity and confidentiality. The data was collected after participants showed a willingness to participate in the study. The participants were not given any incentives or induced with monetary rewards to participate. All the names used in the article are pseudonyms. 


\subsection{Data Collection and Analysis}

The data was collected from 28 semi-structured in-depth interviews and two focus group discussions (FGDs) with women leaders, women in those communities, and relevant stakeholders involved in peacebuilding in Plateau State.

The interviews were conducted by the first author and his two research assistants at the workplaces, homes and common places such as training centres depending on the preferences of the participants. One of the FGDs was conducted at the residence of the leader of one of the women-led association and the other at a training centre for women. The interviews were conducted either in English or in Hausa language and FGDs were conducted in Hausa, which was the most preferred language for the participants. All interviews and FDGs were recorded with the permission of the participants and were later transcribed in English by the first author and research assistants.

The analysis of the data involved reading through the transcripts several times to get acquainted with the data and emerging themes. Based on the aims of the research, the efforts of women in peacebuilding were categorised under two main themes: individual and collective agencies, and the types of agencies under each theme constituted the sub-themes as categorised in the findings section.

\section{Women's Agency: Peacebuilding in Bukuru and Gyel Communities}

Some of the common reactions of people to a conflict are the formation of new group bonds, the reversion to primary groupings and the polarization of conflicting parties along identity lines which contributes to deepening the social divide between the conflicting parties (Belloni, 2008). This has been the case in Bukuru and Gyel communities since after the conflict. The polarized settlement pattern has shaped the narratives and stereotypes that tend to perpetuate the notion of 'us-against-them' in the communities thereby giving room for the possibility of tension and mutual suspicion. Women's agency in such an instance is seen in how women try to change the negative stereotypical narratives and build social cohesion through informal efforts. Women's efforts in these communities were either individual or collective through women-led associations and organisations which aims to facilitate dialogue among women, building trust and empowering women.

\subsection{Women's Agency as a Reactive Effort to the Conflict Experiences of Women}

Women's agency in building peace and social cohesion in the communities is motivated and shaped by the impact of the conflict which has affected women in varying ways. In our interactions with the women during the FGDs and interviews, virtually all the women indicated that the factors that have prompted them to act in peacebuilding activities in their communities relate to their conflict experiences.

All the women were affected by the conflict in their communities. Some of them were affected by the death and injury of loved ones and faced displacement, and most of them experienced the displacement of relatives, loss of means of livelihood and suffered gender-based violence also including rape. They also stated that during and after the conflict they had to pick up new roles and responsibilities like being the bread-winner and provider for their families, caring for the victims of the conflict and also trauma healing for the victims

I lost my husband and my son during the crisis and since then I have been left alone with four children to cater for. It has not been easy, therefore, any process and initiative that would prevent any violence in whatever form and shape, I will totally support. (Lyop, Gyel)

In the beginning, we hid our children, cook for them and the men. After more crisis we got tired of the deaths, so we usually advise our youths and men we want peace. Because the conflicts killed plenty of our men, everyone is suffering our businesses are suffering too. Any community that is always fighting there will not be any progress in that community. (Hajiya Mairo, Bukuru)

Due to the negative impact of this conflict, women have taken up the challenge of not only restoring peace but also ensure that adequate measures are taken to prevent the relapse to violence. This was obvious when they were asked about their motivations to get involved in activities that promote peace.

We women are the ones that are affected by the conflict the most, so we have to do our own part to promote peace. (Mrs. Yop, Gyel)

Looking at the losses of the conflict, we the women saw it necessary to act, this is because we the women felt that enough is enough and we don't want a repeat of any conflict. (Hajiya Hadiza, Bukuru)

The part that women were acting to prevent the relapse to violence and promote peace were at two levels: individual and collective level. These two levels of women's agency are detailed in the next parts. 


\subsection{Individual Women's Agency}

After the conflict women in both communities, women were acting individually as mothers and supporters of the victims of conflict.

\subsubsection{As a Mother: Intra-Family Peacebuilding}

Individually, one of the pathways through which women see themselves as contributors to peacebuilding is related to their social positioning as mothers and care-givers. During the interviews and FGDs, virtually all the women discussed that as mothers, it is their primary responsibility to inculcate values of peace and morality in their children. Thus, the women have been able to use their respected position in the home as mothers to talk to their children and sensitize them on peace and why it is important to live in a peaceful and harmonious environment.

As a mother when you speak, the children often listen because we gave birth to them. Since the conflict, I have been advising my children to avoid mingling with bad friends and shun any act of violence. (Hajiya Salamatu, Bukuru)

Women have contributed to peace by raising up the children in godly ways so that they will grow to embrace peace. We always give stern warnings to our children not to engage in crime, violence and anything that will result to conflict. (Lyop, Bukuru)

As stated by Lyop, in addition to their motherly role, they also use religious teachings as exhorted by the holy books (Bible and Quran).

I always teach my children to love everyone irrespective of the person's religion just as it is taught in the Bible to love your neighbour as yourself. This has played a major role in shaping the behaviour of the children. (FGD 1, Mrs. Victoria)

The role of the women as mothers sometimes went beyond their homes. For instance, Hajiya. Aisha and Mrs. Janet explained that their motherly responsibility is not restricted to their individual families but they extend it to the community where they admonish the youths who in most cases carry out the violence. They assert that mothers have the moral responsibility to discipline any child in the community and report any act of indiscipline to the parents. Thus, they see that as part of their community responsibility in line with Africa's cultural practice that is emphasized in the old adage that 'it takes a community to raise a child'. They have individually used their position as mothers to convince irate youths to calm their frayed nerves and allow for peaceful means of addressing grievances as against resorting to violence.

\subsubsection{Relief Work}

Another important individual peacebuilding effort of women is seen in their relief work. This is usually carried out through visitation of victims of violence and support in areas of needs for the needy in their community.

We care for one another. If something bad happens to one of us (maybe the loss of a family member) we visit such a person to console and empathise with the grieving family (Mrs. Sandra, Gyel).

After the crisis ended, we had to support the families that were affected. Those who were displaced, we provided our own homes as a shelter for them and their children and shared food and clothing at IDP camps. (Mrs. Kate, Gyel)

The relief work is sometimes also carried out as a collective agency as a part of activities of faith-based groups, civil society organizations and women-led associations.

\subsection{Collective Women Agency: Role of Women-Led Associations in Facilitating Dialogue, Building Trust and Empowering Women}

Since 2010, many women-led associations aimed at peacebuilding in Plateau State have emerged (Chima \& Alokpa, 2015) and opened up opportunities for women to be involved in peacebuilding activities collectively.

\subsubsection{Facilitating Dialogue for Building Trust: Plateau Women Peace Initiative}

One of such initiatives that promoted dialogue between Muslim and Christian women is the Plateau Women Peace Initiative (PWPI) a voluntary association for women. The association creates a shared space for women across the religious divides with the main aim of: (i) contributing to the healing process in Plateau State by promoting interpersonal and group dialogue among women (ii) creating a platform for women to participate in building a culture of peace in their communities irrespective of ethno-religious affiliations (iii) empowering women through skill acquisition programmes. 
The peace initiative has been able to facilitate the healing process and restore interpersonal relationships which are constantly changing the narrative and hostile relations in the communities. Changing a narrative of animosity usually takes a gradual process which relies on restoring interpersonal relations, reconciliation and daily interactions. The account by the leader of the PWPI Mrs. Grace who resides in Gyel describes how at the first instance, the women reacted to coming together and how perceptions gradually changed between the Christian and Muslim women. She stated:

Initially, it was not easy at all for the women to relate to each other because of the enmity created by the conflict. I remember our first meeting, the Christian women sat on one side and Muslims too sat together. But gradually, the women started feeling free and began to mingle. Today, that negative perception has changed as they no longer see each other with that deep-rooted hatred but rather as individuals united in promoting peace. We encourage the women to continue to build peace in their community too during our quarterly meetings.

Similar narratives were also reported by women regarding the difficulties of getting together with the other group at the initial stages. During the fieldwork through attending one of the quarterly meetings of PWPI, we had a chance to see and confirm that women mixed up and related freely with each other and there was no sign of hostility or animosity as they conversed and had lunch together.

To facilitate a better healing process, the PWPI constantly collaborates with other civil society organisations and NGOs who organise programmes with women from other communities. This has given the women an opportunity to share stories and experiences of their peacebuilding efforts. The women explained that membership of the association has helped them develop personal relationship and networks among themselves and has transformed animosity to friendship while initiating forgiveness among the women.

Since I joined this association, I have been able to make new friends with Muslim women from Bukuru and I have introduced some of them to my other friends in other parts of Jos. (Mrs Jessica, Gyel)

The association has created a comfortable space for women to discuss issues that affect women in particular.

There are certain issues that affect women that are discussed here and our association tries to find solutions to those issues. (Hajiya Mairo, Bukuru)

The restoration of dialogue, bond, and harmonious relationships among the women has gone a long way in mending the torn social fabric of the communities and has contributed immensely in building trust at the community level. Women have been working to support each other not only on issues related to conflict but also on issues that affected them. In a way, they had become friends again.

\subsubsection{Skill Acquisition for Building Peace: Anis'au Women for Peace and Development}

Women through their organisation have been able to organise vocational and other skill acquisition training programs for women in their respective communities. One of such association is Anis'au Women for Peace and Development in Bukuru community aimed at creating an opportunity for women to develop certain skills that can help them create sustainable livelihood through which they can sustain their families. At inception, it was for young Muslim widows in the community but later expanded to provide skill development for all women and girls. One of the coordinators of the programme Hajiya Murjanatu from Bukuru, although in a gender-stereotyped way, explained how they contribute to building peace by preventing idleness among women:

Women are the number one advocates for peace in their communities. Women are not as secretive as the men, they disseminate information more than the men but idleness makes them gossip and spread rumours which most often tend to be expletive. This organisation is helping them channel that energy positively by coming together and getting engaged. It is a way to enhance peace because they can use these new skills to meaningfully engage their children.

The training programme for women meant more than preventing conflict. Through the programme, women had a chance to get together with other women and overcome the trauma of the conflict.

I am very happy about coming here every day. It has allowed me to meet other women and socialize with them. This is because, since the crisis, I have not been going out often to meet with many women. I have been depressed and this program has helped in overcoming the trauma of the conflict. (Hajiya Bilkisu, Bukuru)

The skill acquisition program has played a major role in bringing the women out of isolation to interact and engage meaningfully with other women. One of the facilitators Hajiya Jummai explained their role as:

By virtue of this programme and the introduction of skill acquisition women's participation has 
increased. There is this woman who stays indoor always but because of the introduction of this programme she now has a reason to come out to mingle with other women (both Christian and Muslim women) and participate in things that can bring peace and empower her. Through this programme, she has gotten more awareness and she will also encourage other women to participate. It will give her an opportunity to change her thoughts or preconceived idea of the women of the other religion whom the conflict has made enemies.

\subsubsection{We Trust Each Other even with Our Monies: Adashe Savings Cooperative}

Another very important way through which women in the polarized post-conflict communities in Plateau State have been empowering themselves is through participating in thrift cooperative. While carrying out the fieldwork, we interacted with the leader and members of a women-led cooperative organisation in Bukuru and Gyel communities known as 'Kungiyar Adashen Matan Kasuwa' (Market Women Thrift Society). The cooperative has a membership of over 64 members. It was formed in 2015 by women who traded in Bukuru market. The cooperative is a contributory saving scheme otherwise known as 'adashe' created by women traders who daily contribute a small percentage or portion of their profit to a collector or coordinator who manages the collections. The members of the cooperative pointed out their satisfaction with the adashe and how it has helped in alleviating against poverty and encouraging them to save.

I am thankful for this adashe oh! At least I am able to save something no matter how little every day...It has really helped me in meeting the needs of me and my yara (children). (Mrs. Esther, a vegetable seller in the popular Gyel Market)

Adashe helps very well. Even in times of emergencies, you can approach the collector and you're able to make take loan. Just like early this year when my daughter fell ill, I ran to the adashe collector and I was able to get some money to pay for the hospital bills and buy drugs. (Mrs. Kaneng, a member of the adashe)

Apart from alleviating poverty and handling emergencies, the women describe how the cooperative has also played a role in building trust which is gradually translating into intergroup relations in the polarized communities. The leader of the adashe cooperative, Mrs Kachollom from Gyel in describing the role of the organisation and its impact on and peacebuilding stated:

We are peace-loving women and care for the welfare of one another. It comprises of market women from Gyel, Du and Bukuru areas. We are united here and the adashe has helped us to put aside any form of fear or suspicion. We trust each other even with our monies.

Consequently, women through their thrift cooperative have been able to engage in positive dialogue with women from other different communities and the result shows that the mutual fear, suspicion and hatred created by the conflict is gradually being transformed to peaceful and cordial relations based on trust.

\subsection{Using Established Networks to Avert the Relapse to Conflict}

One important goal of peacebuilding is the prevention of the relapse to violence. Women from both communities built relationships and networks during their interactions with each other at the activities of women-led associations. They used these networks to defuse tensions and avert violent conflicts in the following ways:

\subsubsection{The Use of Phone Calls to Refute Rumours}

Rumour in a conflict situation has the capacity to instil fear, panic, ignite and escalate conflicts within any community that is prone to conflict. Since the 2001 conflict in Plateau State, the spread of rumours have been responsible for the escalation and the spread of violence. Rumours of the 'Jos crisis' in 2001, 2008, and 2010 spread like wildfire across parts of the state and other neighbouring states (like Kaduna, Kano, Nassarawa) as different groups began to mobilize for reprisals (Danfulani \& Fwatshak, 2002; Krause, 2019). This caused panic and reprisal attacks that worsened the intensity of the conflict. Reprisal attacks have been a common occurrence in Bukuru and Gyel communities as well. Once there are rumours of violence in parts of the state, there is a likelihood for tension to be heightened in the communities. The women explained that the interpersonal relationships and peace networks established in their women-led associations have been useful in averting conflict.

Usually, before any crisis starts, there are always rumours that something has happened here or there or you hear people saying 'an fara' (they have started). Once we in our community hear that there is violence or anything worrisome in the other community, we call our friends from the other community to be sure. In fact like last year, we heard shouting at night and some women phoned me that they heard 
something is happening around Bukuru, I called one of the key peace activist there who later confirmed that it was the youths at a football viewing centre celebrating the victory of their favourite football club at a football viewing centre. So when we hear anything, we try to call each other to be sure and that way we can prevent violence. (Mrs. Noro, Gyel, FGD 1)

Through prompt refuting of rumours, women have been able to sustain peace in their communities. Their efforts go beyond just refuting rumours but also serves as an early warning mechanism.

We women are very observant. Once we see things that are done (mostly by the youths) that can cause problems, we quickly report it to the Mai-Angwa (Community head) or even the police as the case may be. (Hajiya Zainab, FGD 1)

\subsubsection{Peaceful Protest}

Women have collectively organised peace rallies within Jos and environs to preach peace and protest against violence in the communities. The women during one of the focused group discussion explained that instances where there is violence in any part of the state, they join other women to protest to put an end to the killings.

We have always protested against acts of violence in any part of Plateau state. We usually dress in black and carry leaves to signify mourning. We have walked from the Old-Airport junction to the government house and House of Assembly to demand from the government to put an end to all the bloodshed on the Plateau. (Hajiya Halima, FGD 2)

When we come out in our numbers and cry out to the government, they know that we are deeply hurt. You find women from different parts of Plateau irrespective of their religion joining the protest and peace match. (Mrs. Simi, Gyel)

Peace protest as described by the women is usually reactive to mass violence as well as an effort to prevent a further bloodbath. However, most of the women stated that they participate in peace sensitisation programmes and rallies organized by civil society organisations.

\section{Discussions and Conclusion}

The main goal of peacebuilding is to prevent the relapse to violence in post-conflict communities. In this study, we set out to explore the contributions of women in building peace in their polarized post-conflict communities in Plateau State, Nigeria. Through narratives of Muslim and Christian women living in two polarized post-conflict communities, we show how women individually or collectively become contribute towards building and sustaining social cohesion. Through in-depth semi-structured interviews and focus group discussions with women in Bukuru and Gyel communities, the findings indicate that women do play a subtle but very critical role which is gradually transforming the broken relationships in their communities. Shared conflict experiences of women played a major role in shaping their agency in peacebuilding to prevent a relapse to conflict. The study categorizes women's agency into two folds i.e. individual and collective agency.

The individual agency of women is shaped by their role as mothers and care-givers. This motherly role includes the inculcating of good character and peaceful virtues in their children, urging them not to engage in activities that can lead to violence. Mbabazi, Naiga and Helen (2020) emphasize that the nurturing roles of women in their families often give them an added advantage in peacebuilding. On the other hand, their collective agency is carried out through women-led associations that create a space for interpersonal and intergroup dialogues among women as well as engaging in activities that can also empower them such as skill acquisitions and cooperatives saving schemes.

Studies by Birchall (2003) and Ramnarain (2015) indicates that cooperative organisations are very important and play crucial roles in post-crisis situations. As Birchall (2003, p. 25) emphasizes, "Cooperatives have a key role in the recovery process after the crisis" through activities that can empower, meet special needs and reduce poverty. In a similar way, Annan (2006) and International Cooperative Alliance (2006) also assert that due to the nature of how cooperatives operate, they tend to build trust in communities, inculcate principles and values that promote togetherness and tolerance. Our study provides support to these studies by showing the pathways through which women have carried out their collective agency with the help of women-led associations and cooperatives. Associations do not only operate to help women have dialogue, but contribute to women's emotional well-being, skill acquisition and economic empowerment. This has been vital as the women's voices connote that the space created for women through women-led associations has enabled them to establish new bonds and interpersonal relationships with each other. This has gradually contributed to changing the negative stereotypes as well as the 'us-against-them' narratives. They have also used the platform to support each other's businesses which is also contributing to the empowerment of women. The study shows that women have used 
this bond of womanhood to avert conflict by refuting rumours and preaching peace. Their individual and collective efforts transcend their immediate family and are currently positively impacting their communities. It could be stated that their agency has immensely contributed to the current relative peace that is being enjoyed in the communities.

Furthermore, their agency has not only helped in building community bond and bridging the religious divide in the communities, but it has also given room for more cooperation, synergy towards unity irrespective of religious divides. Peacebuilding as a long-term process requires the sustainability of the activities that contribute to the betterment of relationships between conflicting parties. In order to avoid relapse to violence in any conflicting state, it is necessary for the government to explore alternative peacebuilding initiatives, such as those initiated by women in this paper, to be able to develop a more inclusive peacebuilding agenda.

From a broader perspective, in this article, we also show how women's agency as a bottom-up approach to peacebuilding can contribute to long-term peacebuilding efforts of nations, and therefore can complement the existing top-down efforts if given recognition and necessary support.

Future studies should focus on tracking the long-term impact of the efforts of the women in the post-conflict communities, in other parts of Nigeria and the World. The studies should also investigate the challenges faced by women and women-led associations in initiating and sustaining women's agency for peacebuilding.

\section{References}

Adeogun, T. J., \& Muthuki, J. M. (2018). Feminist perspectives on peacebuilding: The case of women's organisations in South Sudan. Agenda, 32(2), 83-92. https://doi.org/10.1080/10130950.2018.1450572

Adetula, V. A. O. (2005). Ethnicity and the dynamics of city politics: the case of Jos. In A. Maliq, Simone, \& A. Abouhani (Eds.), Urban Africa: Changing Contours of Survival in the City (pp. 206-234). London: Zed Books.

Alaga, E. (2010). Challenges for women in Peacebuilding in West Africa. Policy Brief. AISA, Briefing, (18). Retrieved February 14, 2020, from http://www.ai.org.za/wp-content/uploads/downloads/2011/11/No-18.-Challenges-for-Women-in-Peacebuildi ng-in-West-Africa.pdf

Alison, M. H. (2009). Women and Political Violence: Female Combatants in Ethno-National Conflict. London: Routledge. https://doi.org/10.4324/9780203013458

Aliyu, A. A., Abdu, A. A., Rozilah, K., \& David, M. (2015). Residential segregation and existing neighbourhood pattern in Jos metropolis, Nigeria. Journal of Natural Sciences Research, 5, 12-21.

Ambe-Uva, T. N. (2010). Identity politics and the Jos crisis: Evidence, lessons and challenges of good governance. African Journal of History and culture, 2(3), 42.

Annan, K. (2006). Peace-building through Cooperatives. UN-message on the United Nations International day of Cooperatives. Retrieved January 12, 2020, from http://www.ica.coop/activities/idc/2006-unsg-en.pdf

Bar-Tal, D. (2013). Intractable conflicts: Socio-psychological foundations and dynamics. Cambridge University Press. https://doi.org/10.1017/CBO9781139025195

Belloni, R. (2008). State building and international intervention in Bosnia. Routledge. https://doi.org/10.4324/9780203938003

Best, S. G. (2007). Conflict and peace building in Plateau State, Nigeria. Spectrum books limited.

Birchall, J. (2003). Rediscovering the cooperative advantage-Poverty reduction through self-help. International Labour Organisation.

Bonkat, L. (2014). Survival Strategies of Market Women and Violent Conflicts in Jos, Nigeria. Journal of Asia Pacific Studies, 3(3), 281-299.

Bonkat, L. (2015). Surviving in a conflict Environment: Market Women and Changing Socioeconomic Relations in Jos, Nigeria, 2001-2010. (Unpublished doctoral dissertation) Bayreuth University, Germany.

Boutros-Ghali, B. (1992). An agenda for peace: Preventive Diplomacy, Peacemaking and Peace-keeping. New York: United Nations; and Supplement to an Agenda for Peace A/50/60 (3rd of January 1995). https://doi.org/10.1177/004711789201100302

Bryman, A. (2008). Social Research Methods (3rd ed.). Oxford: Oxford University Press.

Chima, P., \& Alokpa, F. (2015). Non-Governmental Organisations and Conflict Management in Plateau State, 
Nigeria. International Journal of Humanities and Social Science, 5(10), 61-70.

Council on Foreign Relations. (2019). Women's Participation in Peace Processes. Retrieved February 29, 2020, from https://www.cfr.org/interactive/womens-participation-in-peace-processes

Creswell, J. W. (2009). Research design: Qualitative and mixed methods approaches. London and Thousand Oaks: Sage Publications.

Danfulani, U. H. D., \& Fwatshak, S. U. (2002) Briefing: The September 2001 Events in Jos, Nigeria. African affairs, 101(403), 243-255. https://doi.org/10.1093/afraf/101.403.243

Egwu, S. G. (2004). Ethnicity and citizenship in urban Nigeria: The Jos case, 1960-2000. (Unpublished doctoral dissertation) University of Jos, Nigeria. Retrieved February 3, 2019, from http://dspace.unijos.edu.ng/bitstream/10485/850/1/Ethnicity\%20and\%20Citizenship\%20in\%20Urban\%20N igeria.pdf

Galama, A., \& van Tongeren, P. (Eds.). (2002). Towards better peacebuilding practice: on lessons learned, evaluation practices and aid \& conflict. International Books.

Galtung, J. (1976). Three Realistic Approaches to Peace: Peacekeeping, Peacemaking, Peacebuilding. Impact of science on society, 26(1-2), 103-115.

Gardner, C. B. (1995). Passing by: Gender and public harassment. London: University of California Press.

Gawerc, M. I. (2006). Peace - building: Theoretical and concrete perspectives. Peace \& Change, 31(4), 435-478. https://doi.org/10.1111/j.1468-0130.2006.00387.x

Gwamna, D. J. (2006). Religion and Ethnic Relations in the Middle. Belt of Nigeria. In Akinwumi, O., Okpeh, O. O., \& Gwamna, D. J. (Eds.), Inter-Group Relations in Nigeria during the 19th and 20th Centuries (pp. 588604). Makurdi: Aboki Publishers.

Harnischfeger, J. (2004). Sharia and control over territory: Conflicts between 'settlers' and 'indigenes' in Nigeria. African Affairs, 103(412), 431-452. https://doi.org/10.1093/afraf/adh038

International Cooperative Alliance. (2006). International Cooperative Day/United Nations International Day of Cooperatives. Retrieved January 12, 2020, from http://www.ica.coop/activities/idc.html

Jeong, H. W. (2002). Peace Building: Operational Imperatives and Organizational Coordination. Hiroshima Peace Science, 24, 1-19.

Kabeer, N. (1999). Resources, agency, achievements: Reflections on the measurement of women's empowerment. Development and change, 30(3), 435-464. https://doi.org/10.1111/1467-7660.00125

Kabeer, N. (2001). Reflections on the measurement of women's empowerment: Theory and practice. Discussing women's empowerment: Theory and Practice. Stockholm: Novum Grafiska, AB.

Kaufman, J. P., \& Williams, K. P. (2013). Women at war, women building peace: Challenging gender norm. Boulder, CO: Kumarian Press.

Keating, T. F., \& Knight, W. A. (Eds.). (2004). Building sustainable peace. United Nations University Press.

Krause, J. (2018). Resilient communities: Non-violence and civilian agency in communal war. Cambridge University Press. https://doi.org/10.7591/cornell/9781501708558.001.0001

Krause, J. (2019). Gender Dimensions of (Non)Violence in Communal Conflict: The Case of Jos, Nigeria. Comparative Political Studies, 52(10), 1466-1499. https://doi.org/10.1177/0010414019830722

Lederach, J. P. (1997). Sustainable reconciliation in divided societies. Washington, DC: USIP.

Mac Ginty, R. (2014). Everyday peace: Bottom-up and local agency in conflict-affected societies. Security Dialogue, 45(6), 548-564. https://doi.org/10.1177/0967010614550899

Madueke, K. L. (2018). From neighbours to deadly enemies: excavating landscapes of territoriality and ethnic violence in Jos, Nigeria. Journal of contemporary African studies, 36(1), 87-102. https://doi.org/10.1080/02589001.2017.1410529

Marchbank, J. (2000). Women, power and policy: Comparative studies of childcare. Psychology Press.

Mbabazi, V., Naiga, R., \& Helen, N. N. (2020). Towards a Gendered Peacebuilding Processes for Sustainable Peace. Jadavpur Journal of International Relations. https://doi.org/10.1177/0973598419896441

Milligan, M. (2013). Fighting for the Right to Exist: Institutions, Identity, and Conflict in Jos, Nigeria. 
Comparative Politics, 45(3), 313-334. Retrieved April 16, 2020, from www.jstor.org/stable/43664323

Mishra, N. K., \& Tripathi, T. (2011). Conceptualising women's agency, autonomy and empowerment. Economic and Political Weekly, 58-65.

Moser, C. \&. Clark F. C. (2001). Victims, Perpetrators or Actors? Gender, Armed Conflict, and Political Violence. London: Zed Books.

Mustapha, A. R., Higazi, A., Lar, J., \& Chromy, K. (2018). Jos: Fear \& Violence in central Nigeria. In Mustapha, A. R., \& Ehrhardt, D. (Eds.), Creed \& Grievance: Muslim-Christian Relations \& Conflict Resolution in Northern Nigeria (pp. 225-268). Woodbridge, Suffolk; Rochester, NY: Boydell \& Brewer. https://doi.org/10.1017/9781787442375.011

Noma, E., Aker, D., \& Freeman, J. (2012). Heeding Women's Voices: Breaking Cycles of Conflict and Deepening the Concept of Peacebuilding. Journal of Peacebuilding \& Development, 7(1), 7-32. https://doi.org/10.1080/15423166.2012.719384

Oda, H. (2007). Peacebuilding from Below: Theoretical and Methodological Considerations toward an Anthropological Study on Peace. Journal of the Graduate School of Letters, 2, 1-16.

Olsson, L., \& Gizelis, T. I. (2014). Advancing gender and peacekeeping research. International Peacekeeping, 21(4), 520-528. https://doi.org/10.1080/13533312.2014.946742

Ostien, P. (2009). Jonah Jang and the Jasawa: Ethno-religious conflict in Jos, Nigeria. Muslim-Christian Relations in Africa. Retrieved December 15, 2019, from http://www.shariain-africa.net/media/publications/ethno-religious-conflict-in-JosNigeria/Ostien_Jos.pdf

Paffenholz, T. (2014). International peacebuilding goes local: analysing Lederach's conflict transformation theory and its ambivalent encounter with 20 years of practice. Peacebuilding, 2(1), 11-27. https://doi.org/10.1080/21647259.2013.783257

Paffenholz, T., \& Spurk, C. (2006). Civil society, civic engagement, and peacebuilding. Social Development Papers: Conflict Prevention and Reconstruction, 36, 10-55.

Paris, R. (2004). At war's end: building peace after civil conflict. Cambridge University Press. https://doi.org/10.1017/CBO9780511790836

Ramnarain, S. (2015). Interrogating women's peace work: community-based peacebuilding, gender, and savings' co-operatives in post-conflict Nepal. Community Development Journal, 50(4), 677-692. https://doi.org/10.1093/cdj/bsu065

Ramsbotham, A., Bah, A. M., \& Calder, F. (2005). Enhancing African peace and security capacity: a useful role for the UK and the G8?. International Affairs, 81(2), 325-339. https://doi.org/10.1111/j.1468-2346.2005.00453.x

Rodríguez, J. O., Pillai, V. K., \& Ferreira, M. R. (2016). The impact of women's agency and autonomy on their decision-making capacity in Nuevo Leon, Mexico. Acta Universitaria, 26(5), 70-78. https://doi.org/10.15174/au.2016.976

Sodiq, Y. (2009). Can Muslims and Christians live together peacefully in Nigeria?. The Muslim World, 99(4), 646-688. https://doi.org/10.1111/j.1478-1913.2009.01292.x

van Tongeren, P. (2013). Potential cornerstone of infrastructures for peace? How local peace committees can make a difference. Peacebuilding, 1(1), 39-60. https://doi.org/10.1080/21647259.2013.756264

\section{Copyrights}

Copyright for this article is retained by the author(s), with first publication rights granted to the journal.

This is an open-access article distributed under the terms and conditions of the Creative Commons Attribution license (http://creativecommons.org/licenses/by/4.0/). 